\title{
Effect of plant density on biomass yield of Cynara cardunculus
}

M. Sanz, P.V. Mauri, M.D. Curt, J. Sánchez, M. García-Mü ller, A. Plaza and J. Fernández

\begin{abstract}
Cynara cardunculus $\mathrm{L}$. is a perennial herb that has been proposed as an energy crop in Mediterranean environments because of its adaptation to dry and hot summers. Plant density is an important factor for biomass production but it is related to water availability; therefore, in water-constrained conditions it should be optimized. In this work the effect of plant density on the production of $\boldsymbol{C}$. cardunculus is studied at field level in the rain-fed conditions of central Spain. The experiment was conducted under Mediterranean-continental conditions, $430 \mathrm{~mm}$ annual rainfall and 3-month dry period, on average. Sowing was carried out beginning autumn by means of a seed driller with $0.80 \mathrm{~cm}$ between rows. After one-year establishment, two plant densities were compared in 1-ha plots: the standard plant density and a sparse plant density, designed as a double-row system; it was achieved by lifting two out of four crop rows. Treatments were evaluated for plant density, stalk density, number of heads, plant height, biomass production and dry matter content in summertime. Cynara plants tended to be higher ( $215 \mathrm{vs.} 205 \mathrm{~cm})$ and more productive $(0.83 \mathrm{vs} .0 .69$

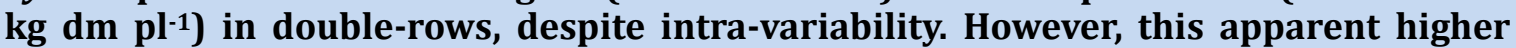
growth did not compensate the reduced plant density and finally, the yield in biomass was lower than in the single-row treatment ( $8 \mathrm{vs} .13 \mathrm{t} \mathrm{dm} \mathrm{ha-1}$ harvestable biomass). Moreover, a higher proportion of cauline leaves was recorded, which affected the quality of the biomass as a solid biofuel since $\mathbf{N}$ content is usually higher in leaves than in stems. Therefore, evidence was provided that the double-row design does not result in yield improvement.
\end{abstract}

Keywords: cardoon, energy crop, biomass yield, crop management

\section{INTRODUCTION}

Cynara cardunculus L., commonly known as cardoon or cynara, is a perennial herb with an annual growth cycle that extends from autumn to summer, season in which the aboveground plant parts dry up and seeds are ripe. Contrary to artichoke, for energy purposes it is grown according its life form. The crop is harvested every year in summertime and re-grows in early autumn. Seeds can be separately harvested for oil and the lignocellulosic biomass for solid biofuel (Fernández et al., 2006). C. cardunculus, as a Mediterranean native species (Wiklund, 1992), is adapted to Mediterranean climates, which are characterized by low annual precipitation, irregular rainfall distribution and hot and dry summers. These conditions represent a limitation for most energy crops if no irrigation is supplied. The adaptive advantage of this species along with other characteristics, like the high biomass potential and the double application (solid and liquid biofuels) of the crop produce, make Cynara an interesting energy crop for dry farming in Mediterranean environments.

Research on Cynara as an energy crop has been carried out in Spain and other European countries in the framework of a number of $\mathrm{R}+\mathrm{D}+\mathrm{i}$ Programmes. Progress has been made in many different areas, i.e., management techniques, yields, biomass properties, applications, densification, oil characterisation, biodiesel and others. As other crops in dry 
farming, yields are dependent on rainfall. Another important factor for biomass production is plant density; as a rule of thumb, the higher the plant population, the higher the biomass production ha ${ }^{-1}$ is. By using dense plantations other effects may arise like changes in plant growth habit (branching, height) and competence for water. Thus, in water-constrained conditions it is extremely important to optimize plant density. The effect of this factor on biomass yield of Cynara has been little investigated. A previous work was the study by Raccuia et al. (2011), which was conducted in $20-\mathrm{m}^{-2}$ plots in Sicily.

In this work the effect of two plantation designs of the Cynara energy crop, leading to different plant densities, was studied in a large-field experiment conducted in dry farming in central Spain. Plant traits, biomass production and biomass partitioning were determined at harvest time for the designs of single rows and double-rows.

\section{MATERIALS AND METHODS}

\section{Location and plant material}

The experiment was carried out in the property 'El Encín' of IMIDRA (Instituto Madrileño de Investigación y Desarrollo Rural, Agrario y Alimentario) at latitude $40^{\circ} 31^{\prime} 12^{\prime \prime} \mathrm{N}$; longitude $3^{\circ} 18^{\prime} 13^{\prime \prime} \mathrm{W}$, altitude $603 \mathrm{~m}$ a.s.l. This is an experimental farm of the Autonomous Community of Madrid (Spain), sited in the municipality of Alcalá de Henares (Figure 1).

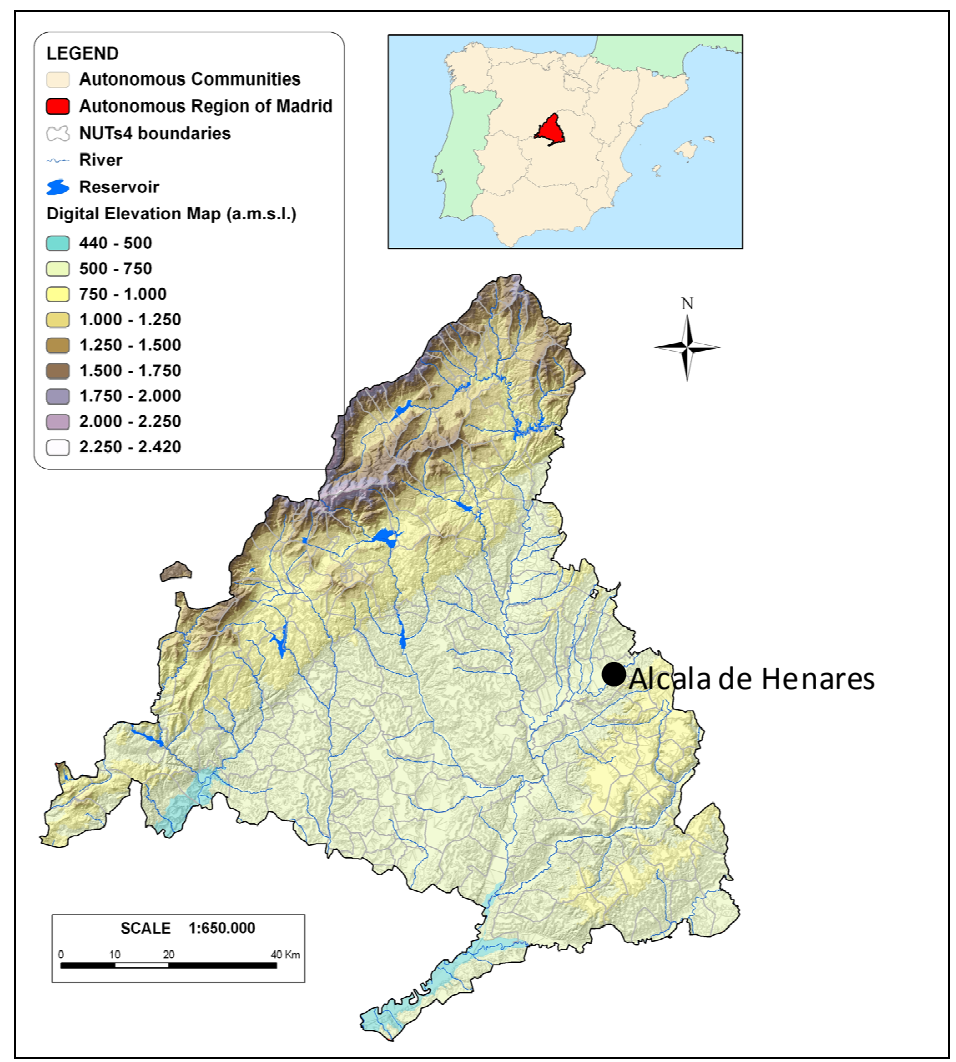

Figure 1. Location and digital elevation map of the Autonomous Region of Madrid (Spain).

The field area devoted to this crop was 20 ha. The soil was an Alfisol (USDA soil taxonomy), more specifically, Haploxeralf Calcic. At this site, the climate is Xeric Mediterranean, sub-type Mild Meso-Mediterranean, commonly described as continentalMediterranean. Based on historical records (1957 to 2000), the climate data of the average year are: $13.4^{\circ} \mathrm{C}$ mean temperature, $60 \%$ relative humidity, $1.8 \mathrm{~m} \mathrm{~s}^{-1}$ wind speed, $309.8 \mathrm{cal}$ $\mathrm{cm}^{-2}$ day $^{-1}$ global radiation, 429.7 annual rainfall and $744.9 \mathrm{~mm} \mathrm{y}^{-1}$ ETP (Thornthwaite) 
(Mauri, 2000).

Plant material for this work came from a previous crop of $C$. cardunculus var. altilis conducted by the Agro-Energy Group of UPM, which was originated from a seed population selected for biomass production (see also Curt et al., 2002).

\section{Crop conditions and crop management}

The field was subsoiled, ploughed and harrowed in September to be physically prepared for sowing. Specific soil characteristics were determined at the design of the treatments (see next sub-section). In order to describe the climate conditions during the experiment, the records of temperature and precipitation were compiled from the closest meteorological station, located in San Fernando de Henares (Madrid, Spain).

The crop was established from seeds. Sowing was carried out in October by means of a seed driller (4-5 kg seeds ha $^{-1}$ ) working with $0.80 \mathrm{~cm}$ separation between rows. Plants developed according the natural cycle of this plant species, dried up in summertime and regrew soon after the first autumn rainfalls. As described in the literature, the year of sowing is for the establishment of the crop; in dry Mediterranean conditions the growth of the aboveground plant parts is usually low in the first year and no harvest is performed until the end of the second growth cycle (first productive year).

Fertilization was conducted soon after the autumn re-growth; $450 \mathrm{~kg} \mathrm{ha}^{-1}$ of 15:15:15 complex fertilizer were applied. Preventive pest control (a.i. dimethoate) was carried out in February against Cassida (see Iglesias et al., 1999). Harvesting was accomplished the first week of September, once the $2^{\text {nd }}$ growth cycle was over.

\section{Treatments}

In order to study the effect of plant density on crop performance and biomass yield, two attached plots sizing 1 ha each were signposted in autumn for plant density treatments. One plot represented the Cynara standard plantation design in rows $0.80 \mathrm{~cm}$ apart; plant density was maintained as it was at that time (Treatment SR). The other plot aimed at a double-row plantation design; it was achieved by lifting two out of four crop rows (Treatment PR). This way the new-designed plot would contain about half the plant population of the rest of the field (Figure 2). Soil characteristics were determined according standard methods (MAPA, 1994) and on average were $\mathrm{pH}$ 8.3, EC $0.18 \mathrm{dS} \mathrm{m}^{-1}$, organic matter 0.5\%, P 18 ppm, $\mathrm{K}\left(\mathrm{AcNH}_{4}\right) 463$ ppm.

In summertime (first week of September) both treatments were evaluated for plant traits and biomass production. Samplings were performed by hand, taking at random six replications of $32 \mathrm{~m}^{2}$ each, per treatment. The parameters studied were the following: plant density, stem density, number of well-developed heads, plant height, harvestable biomass (stem + cauline leaves + heads), whole biomass (harvestable biomass plus basal leaves) and dry matter content. Dry matter content was determined after drying at $105^{\circ} \mathrm{C}$ until constant dry weight. Yields were expressed on a dry biomass basis.

\section{Statistical analysis}

Comparison between treatments was performed by means of an ANOVA test over the following parameters: plant density, stem density, number of well-developed heads, plant height and biomass production. Statgraphics Centurion XVI v.16.08.08 software was used for the mentioned analyses. Significance was accepted at $\mathrm{p} \leq 0.05$ level. 

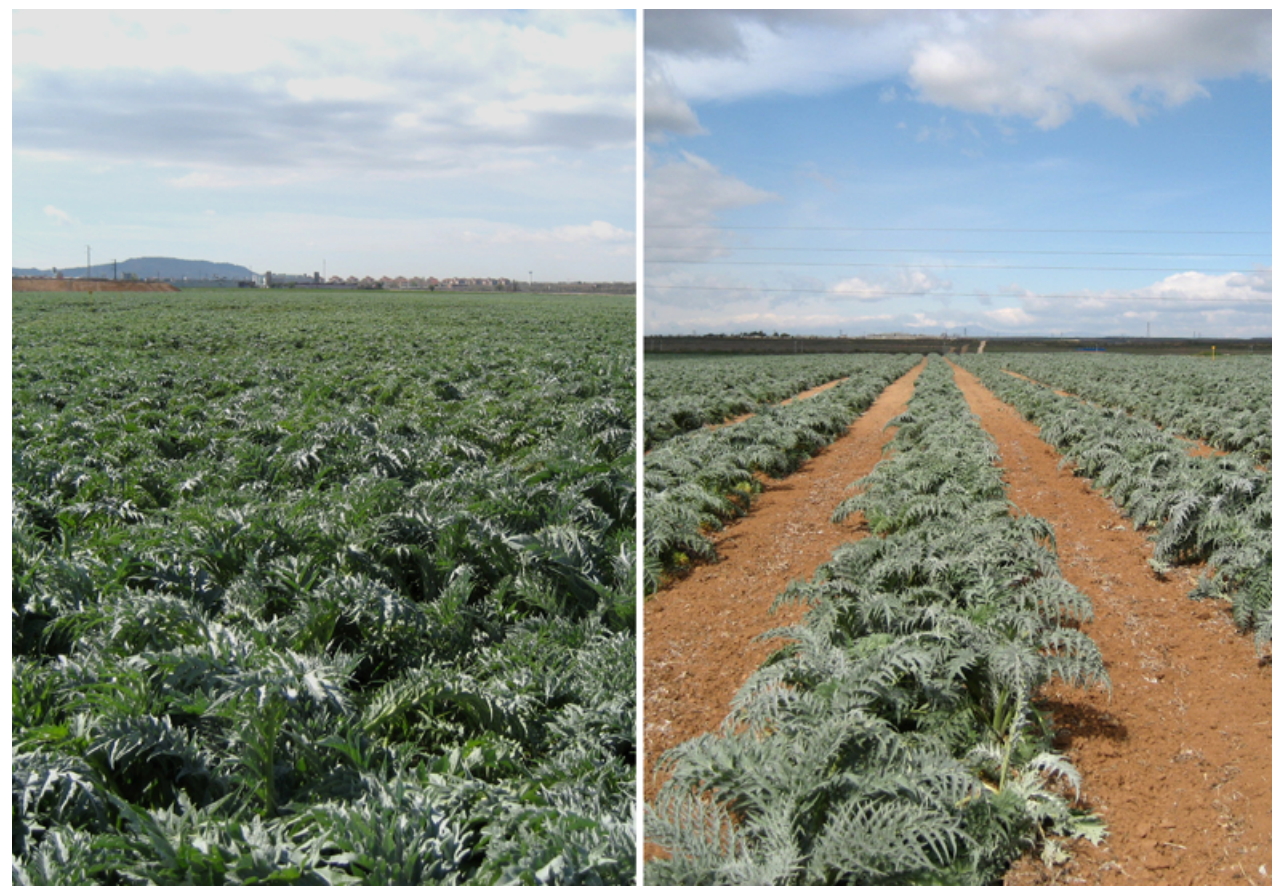

Figure 2. View of the plots. Left: single-row design. Right: double-row design.

\section{RESULTS AND DISCUSSION}

In dry-farming under a Mediterranean environment, the most important factor is the precipitation, in terms of both quantity and distribution. At the experiment site the average precipitation is nearly $430 \mathrm{~mm}$ and the dry period typically lasts 3 months, i.e., from June to September. In our experiment, the establishment year ( $1^{\text {st }}$ growth cycle) was drier than the average year, as shown by the records of precipitation $(394.4 \mathrm{~mm}$ ) and evapotranspiration. On the contrary, the $2^{\text {nd }}$ cycle was above average with $534.4 \mathrm{~mm}$ annual precipitation (Table 1). Rainfall distribution was typically Mediterranean (Figure 3).

Table 1. Climate data. Tmax, absolute maximum temperature; $\mathrm{tm}$, mean temperature; Tmin, absolute minimum temperature; pp, precipitation, ETo, evapotranspiracion; Rg, global radiation.

\begin{tabular}{lcc}
\hline & $\begin{array}{c}\text { Crop establishment } \\
\text { (1st } \text { growth cycle) }\end{array}$ & $\begin{array}{c}\text { First productive year } \\
\left(\mathbf{2}^{\text {nd }} \text { growth cycle) }\right.\end{array}$ \\
\hline $\operatorname{Tmax}\left({ }^{\circ} \mathrm{C}\right)$ & 37.5 & 39.3 \\
$\operatorname{tm}\left({ }^{\circ} \mathrm{C}\right)$ & 14.0 & 14.1 \\
$\operatorname{Tm}\left({ }^{\circ} \mathrm{C}\right)$ & -6.6 & -7.0 \\
pp $\left(\mathrm{mm} \mathrm{year}^{-1}\right)$ & 394.4 & 534.4 \\
ETo $\left(\mathrm{mm} \mathrm{year}^{-1}\right)$ & 1233.3 & 1162.2 \\
$\operatorname{Rg}\left(\mathrm{MJ} \mathrm{m}^{-2}\right)$ & 207.7 & 195.3 \\
\hline
\end{tabular}




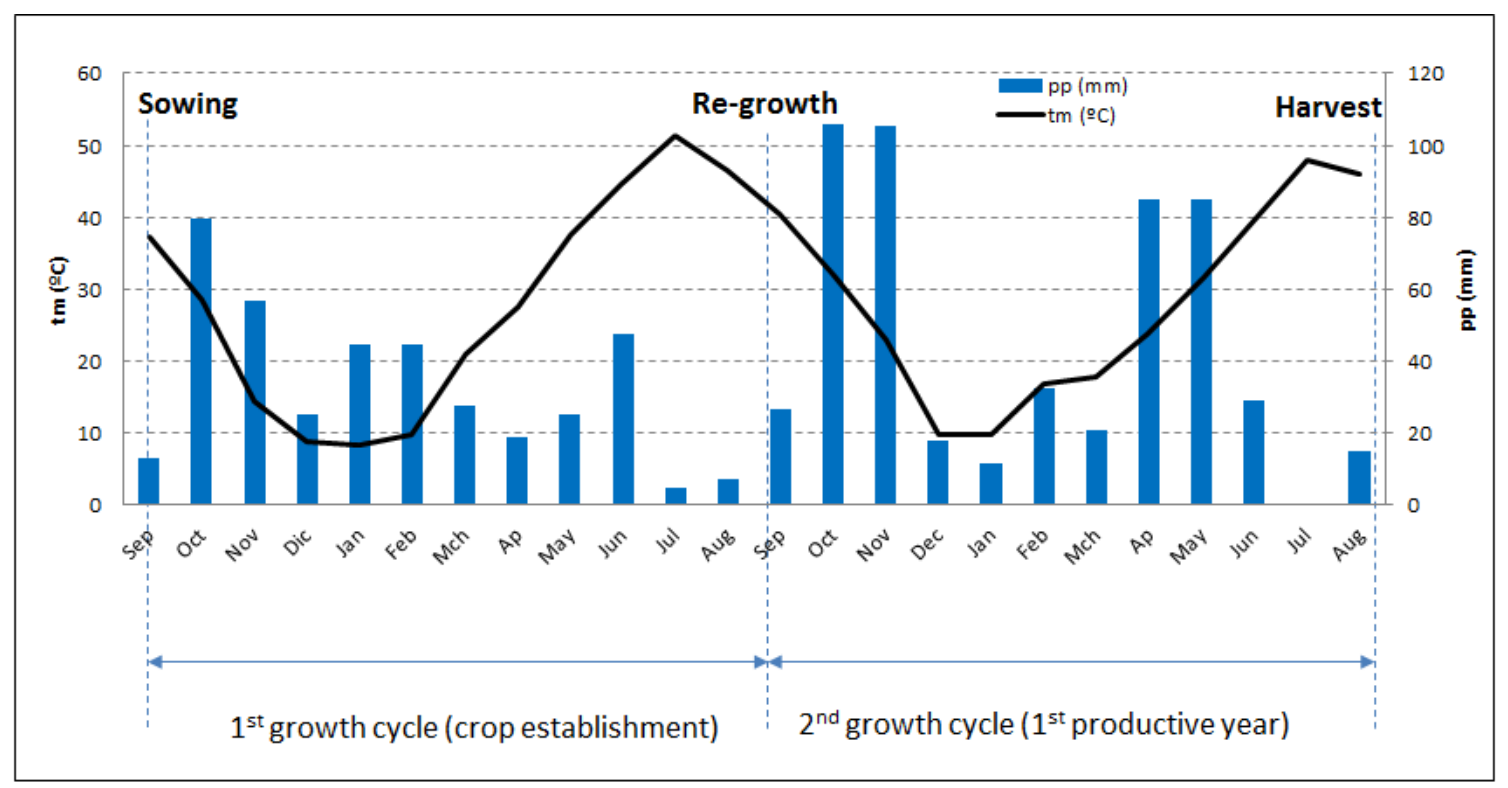

Figure 3. Ombrothermic diagram; tm, mean monthly temperature $\left({ }^{\circ} \mathrm{C}\right)$; pp, monthly precipitation $(\mathrm{mm})$.

\section{Actual plant density}

By actual plant density it was meant the actual plant population determined at harvest time. In the standard plantation design (Treatment SR), the value found for actual plant density was 27,786 plants ha $^{-1}$ which represented a high plant population since it was equivalent to only $0.45 \mathrm{~m}$ plant spacing within a row. For the double-row design (PR) the actual plant population was 12,655 plants ha-1 $^{-1}$ This value was equivalent to 0.49 m distance between plants in a plant row, a value similar to SR, but in the PR treatment plants benefited from more space at one row side due to the double-row design. In the opinion of Fernández (2009) the recommended plant density of cynara energy crop in Spain is about 15,000 plants ha-1. Therefore, the actual plant density in our double-row design would be close to the recommended value while SR would represent a highly populated plantation.

\section{Plant traits and biomass production}

The Cynara crop performed well in both treatments. Plants grew more in height $(215$ vs. $205 \mathrm{~cm}$ ), produced more heads (5.56 vs. 4.38 heads plant $^{-1}$ ) and yielded more biomass ( 0.83 vs. $0.69 \mathrm{~kg} \mathrm{dm}^{-1}$ whole biomass plant ${ }^{-1}$ ) in the double-row treatment than in single rows. In addition, biomass partitioning was better in PR than in SR since the proportion of basal leaves was lower in PR than in SR (26.0 vs. $28.1 \%$ on whole biomass basis). Therefore, it was revealed that a reduced plant density (12,655 vs. 27,786 plants ha-1) enhanced Cynara plant growth.

The results of plant traits, biomass production and biomass partitioning of both treatment, in terms of crop area, are shown in Tables 2 and 3. It is worth mentioning that the values found for the coefficients of variation were generally within the range of the expected values for field trials $(<25 \%)$, in spite of the fact that the plantation was established from seeds and that this plant species is allogamous. At the date of harvest the aboveground plant parts were fully dry; the dry matter content was 85.5 and $89.1 \%$ on average, for the treatments PR and SR.

In terms of crop area, the yields in harvestable biomass amounted to 8.2 and $13.3 \mathrm{t}$ $\mathrm{dm}^{-1} \mathrm{ha}^{-1}$ for the PR and SR treatments, respectively, as a result of the values found for actual plant density (Table 2). These values are consistent with the yields reported for a long-term experiment of Cynara conducted in another site of Madrid, which ranged from 3.4 to $25.2 \mathrm{t}$ $\mathrm{dm}^{-1} \mathrm{ha}^{-1}$ year-1 depending on the rainfall varying from 280 to $588 \mathrm{~mm}^{-1}$ year-1 $^{-1}$ (Fernández et 
al., 2005).

Table 2. Mean values of plant and stem density, canopy height (Hmax), height of the shortest stem (Hmin) and yield in harvestable biomass for the treatments of double rows (PR) and single rows (SR). Between brackets, coefficients of variation (\%). Significance: ${ }^{* * *} \mathrm{p}<0.001$, ns $=$ not significant.

\begin{tabular}{lccc}
\hline Parameter & PR & SR & Significance \\
\hline Plants m-2 & $1.3(11.5)$ & $2.8(13.0)$ & $* \star *$ \\
Stems m${ }^{-2}$ & $2.0(22.0)$ & $4.6(18.9)$ & $* * *$ \\
Heads m-2 & $10.7(22.6)$ & $19.7(15.5)$ & $* * *$ \\
$\mathrm{H} \max (\mathrm{cm})$ & $214.8(4.6)$ & $204.6(5.8)$ & $\mathrm{ns}$ \\
$\mathrm{H} \min (\mathrm{cm})$ & $90.3(18.1)$ & $92.5(14.0)$ & $\mathrm{ns}$ \\
Yield $\left(\mathrm{kg} \mathrm{dm}^{-1} \mathrm{~m}^{-2}\right)$ & $0.82(11.9)$ & $1.33(13.4)$ & $* * *$ \\
\hline
\end{tabular}

Table 3. Results of biomass partitioning (harvestable biomass, \% on dry weight basis) for the treatments of double rows (PR) and single rows (SR). Between brackets, coefficients of variation (\%). Significance: ns = not significant.

\begin{tabular}{lccc}
\hline Plant fraction & PR & SR & Significance \\
\hline Cauline leaves & $25.6(18.7)$ & $19.7(24.6)$ & $\mathrm{ns}$ \\
Stems & $29.1(13.0)$ & $31.6(20.5)$ & $\mathrm{ns}$ \\
Heads & $45.3(9.7)$ & $48.7(11.1)$ & $\mathrm{ns}$ \\
\hline
\end{tabular}

Concerning crop water efficiency at the field level, it was calculated as the ratio between harvestable biomass and annual rainfall. In our experiment it was estimated at 1.53-2.49 $\mathrm{g} \mathrm{L}^{-1}$ depending on the density treatment, for the dry conditions of central Spain.

The analysis of variance showed high significant differences between treatments for the variables: actual plant density (plants $\mathrm{m}^{-2}$ ), stem density (stems $\mathrm{m}^{-2}$ ), number of heads (n $\mathrm{m}^{-2}$ ) and biomass production (dry weight $\mathrm{m}^{-2}$ ) but not for height (Hmax and Hmin) or biomass partitioning (\%) (Table 3). It became evident that the yield was very sensitive to the factor studied although possible changes in plant architecture - plant height, biomass partitioning - were not significant. The enhanced growth of Cynara under the PR treatment did not compensate the effect of the lower plant density and resulted in lower yields in biomass and heads.

\section{CONCLUSION}

The performance of $C$. cardunculus, grown according a standard plantation design (single rows, $0.80 \mathrm{~m}$ apart), was compared to a double-row plantation design that halved the plant density. In both treatments the crop performed well and the results of plant traits and biomass production were consistent with other experiments in dry farming. The trend observed was that plants grew more in height and produced more heads and biomass in the double-row treatment than in single rows. However, in terms of crop area, that apparent enhanced growth did not compensate the effect of the reduced plant density on crop yield. Therefore it can be concluded that the reduced plant density - plantation design in double rows - does not result in a yield improvement of this energy crop.

\section{ACKNOWLEDGEMENTS}

Financial support from the EU Commission (Project BIOCARD, FP6-19829) and the Ministry of Science and Innovation of Spain (Project PROBIOCOM, RTA2012-00082-C02) is gratefully acknowledged.

\section{Literature cited}

Curt, M.D., Sánchez, G., and Fernández, J. (2002). The potential of Cynara cardunculus L. for seed oil production in 
a perennial cultivation system. Biomass Bioenergy 23 (1), 33-46 http://dx.doi.org/10.1016/S09619534(02)00030-2.

Fernández, J. (2009). El Cultivo de Cardo (Cynara cardunculus L.) para Producción de Biomasa. Núm. 2130 HD (Ministerio de Medio Ambiente y Medio Rural y Marino), pp.44, ISBN 978-84-491-0890-7.

Fernández, J., Hidalgo, M., del Monte, J.P., and Curt, M.D. (2005). Cynara cardunculus L. as a perennial crop for nonirrigated lands: yields and applications. Acta Hortic. 681, 109-116 http://dx.doi.org/10.17660/ActaHortic. 2005.681.10.

Fernández, J., Curt, M.D., and Aguado, P.L. (2006). Industrial applications of Cynara cardunculus L. for energy and other uses. Ind. Crops Prod. 24 (3), 222-229 http://dx.doi.org/10.1016/j.indcrop.2006.06.010.

Iglesias, C., Varés, L., and Sinobas, J. (1999). Incidencia de Sphaeroderma rubidum Graëlls y Cassida deflorata Suffrian en el cultivo del cardo (Cynara cardunculus L.). Bol. Sanid. Veg., Plagas 25, 221-228.

MAPA. (Ministerio de Agricultura, Pesca y Alimentación). (1994). Métodos Oficiales de Análisis. Tomo III, Métodos Oficiales de Análisis de Plantas y Suelos (España), pp.662.

Mauri, P.V. (Coord.). (2000). "El Encín". Clima, Suelo y Vegetación (Consejería de Medio Ambiente, Comunidad de Madrid, MARM), pp188, ISBN 84-451-1865-X.

Raccuia, S.A., Gallo, G., and Melilli, M.G. (2011). Effect of plant density on biomass and grain yields in Cynara cardunculus var. altilis cultivated in Sicily. Acta Hortic. 942, 303-308 https://doi.org/10.17660/ ActaHortic.2012.942.43.

Wiklund, A. (1992). The genus Cynara L. (Asteraceae-Cardueae). Bot. J. Linn. Soc. 109 (1), 75-123 http://dx.doi.org/10.1111/j.1095-8339.1992.tb00260.x. 